\title{
НЕСИММЕТРИЧНО ЗАМЕЩЕННЫЙ ФТАЛОЦИАНИН ЦИНКА АЗВ ТИПА, СОДЕРЖАЩИЙ ТИОЛЬНУЮ ГРУППУ: СИНТЕЗ И ФОТОХИМИЧЕСКИЕ СВОЙСТВА
}

\author{
Е.О. Моисеева, А.Д. Косов, Т.В. Дубинина \\ Химический факультет, Московский государственный университет им. М.В. Ломоносова, \\ 119991, Россия, Москва, Ленинские горы, 1.
}

DOI:10.19163/MedChemRussia2021-2021-389Ｅ-mail: ekaterina.moiseeva@chemistry.msu.ru

Фталоцианины нашли применение в качестве фотосенсибилизаторов для ФДТ. Проходят клинические испытания либо допущены в клинику препараты на основе фталоцианинов: Фотосенс и Тиосенс (Россия), Фталоцианин Рс4 (США) и Photocyanine (Китай). Интерес к фталоцианинам с тиольными группами обусловлен возможностью получения на их основе гибридных наночастиц. Сера легко образует ковалентную связь с Au и Ag, которые хорошо проявили себя в таргетной доставке фотосенсибилизаторов для ФДТ.

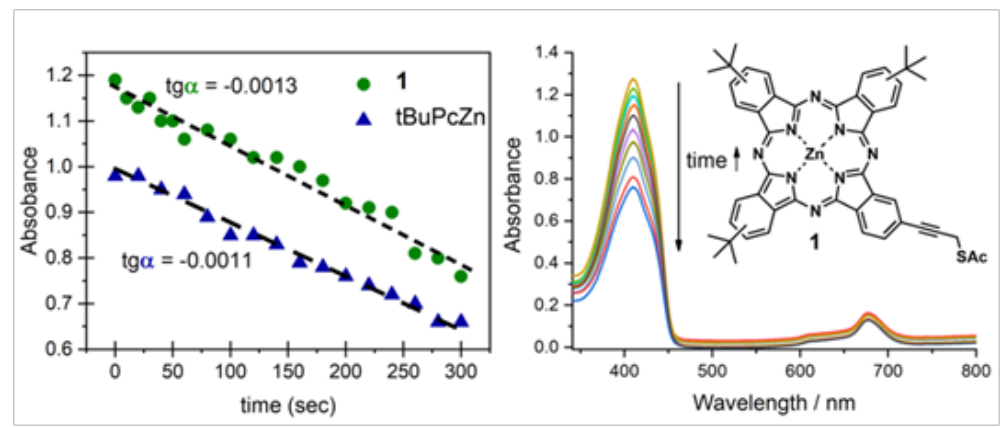

Рис. 1. Определение квантового выхода генерации $\mathrm{O}_{2}{ }_{2}$. Зависимости абсорбции ловушки от времени (слева) и от длины волны (справа) в присутствии комплекса 1 в этаноле.

В настоящей работе осуществлен четырёхстадийный синтез низкосимметричного моно-(пропаргил-тиоацетил)-замещенного фталоцианинина цинка 1 из 4-йодфталонитрила. Введение в целевую молекулу на последней стадии синтеза объёмных mpem-бутильных групп способствует снижению агрегации и улучшению растворимости в таких растворителях, как этанол и ДМСО. Фталоцианин 1 является перспективным соединением для последующего получения на его основе фотоактивных гибридных наночастиц. С целью изучения собственной фотоактивности целевого комплекса определен выход генерации $\mathrm{O}_{2}{ }^{1}\left(\Phi_{\Delta}\right)$ методом «химической ловушки» (1,3 - DPBF) в этаноле. Показано, что полученное значение $\Phi_{\Delta}=0.60 \pm 0.05$ сопоставимо с описанными значениями для феофорбида а $\left(\Phi_{\Delta}=0.62\right)$ и mpem-бутилзамещенного фталоцианина цинка $\left(\Phi_{\Delta}=0.60\right)$.

Работа выполнена при поддержке гранта РФФИ (грант №18-53-76006 Эра). 